\title{
Dimerization of inositol monophosphatase Mycobacterium tuberculosis SuhB is not constitutive, but induced by binding of the activator $\mathbf{M g}^{2+}$
}

Alistair K. Brown ${ }^{1 *}$, Guoyu Meng ${ }^{1,4}$, Hemza Ghadbane ${ }^{1 *}$, David J. Scott ${ }^{2}$, Lynn G. Dover ${ }^{1}$, Jérôme Nigou $^{3}$, Gurdyal S. Besra ${ }^{1 \S}$ and Klaus Fütterer ${ }^{1}$

\section{Additional file 3: Supplementary Information}

References for PDB entries cited in Table 2 of the main text.

1IMA - [1]; 2CZH - [2]; 2BJI - [3]; 1FBP - [4]; 1DCU - [5]; 1LBV - [6]; 1DK4 - [7]; 1QGX - [8]; 1INP - [9]; $1 \mathrm{JP} 4-[10]$

1. Bone R, Frank L, Springer JP, Pollack SJ, Osborne SA, Atack JR, Knowles MR, McAllister G, Ragan CI, Broughton HB, et a: Structural analysis of inositol monophosphatase complexes with substrates. Biochemistry 1994, 33:9460-9467.

2. Arai R, Ito K, Ohnishi T, Ohba H, Akasaka R, Bessho Y, Hanawa-Suetsugu K, Yoshikawa T, Shirouzu M, Yokoyama S: Crystal structure of human myo-inositol monophosphatase 2, the product of the putative susceptibility gene for bipolar disorder, schizophrenia, and febrile seizures. Proteins 2007, 67:732-742.

3. Gill R, Mohammed F, Badyal R, Coates L, Erskine P, Thompson D, Cooper J, Gore M, Wood S: High-resolution structure of myo-inositol monophosphatase, the putative target of lithium therapy. Acta Crystallogr D Biol Crystallogr 2005, 61:545-555.

4. Liang JY, Huang S, Zhang Y, Ke H, Lipscomb WN: Crystal structure of the neutral form of fructose 1,6-bisphosphatase complexed with regulatory inhibitor fructose 2,6-bisphosphate at 2.6-A resolution. Proc Natl Acad Sci U S A 1992, 89:2404-2408.

5. Chiadmi M, Navaza A, Miginiac-Maslow M, Jacquot JP, Cherfils J: Redox signalling in the chloroplast: structure of oxidized pea fructose-1,6-bisphosphate phosphatase. EMBO J 1999, 18:6809-6815.

6. Stieglitz KA, Johnson KA, Yang H, Roberts MF, Seaton BA, Head JF, Stec B: Crystal structure of a dual activity IMPase/FBPase (AF2372) from Archaeoglobus fulgidus. The story of a mobile loop. J Biol Chem 2002, 277:22863-22874.

7. Stec B, Yang H, Johnson KA, Chen L, Roberts MF: MJ0109 is an enzyme that is both an inositol monophosphatase and the 'missing' archaeal fructose-1,6-bisphosphatase. Nat Struct Biol 2000, 7:1046-1050.

8. Albert A, Yenush L, Gil-Mascarell MR, Rodriguez PL, Patel S, Martinez-Ripoll M, Blundell TL, Serrano R: X-ray structure of yeast Hal2p, a major target of lithium and sodium toxicity,

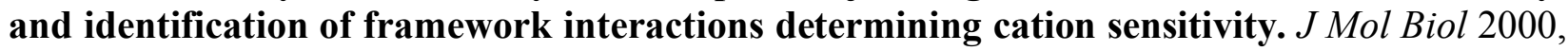
295:927-938.

9. York JD, Ponder JW, Chen ZW, Mathews FS, Majerus PW: Crystal structure of inositol polyphosphate 1-phosphatase at 2.3-A resolution. Biochemistry 1994, 33:13164-13171.

10. Patel S, Yenush L, Rodriguez PL, Serrano R, Blundell TL: Crystal structure of an enzyme displaying both inositol-polyphosphate-1-phosphatase and 3'-phosphoadenosine-5'phosphate phosphatase activities: a novel target of lithium therapy. $\mathrm{J} \mathrm{Mol} \mathrm{Biol} \mathrm{2002,}$ 315:677-685. 